Proc. Estonian Acad. Sci. Eng., 2003, 9, 1, 34-58

\title{
On the crawl space moisture control in buildings
}

\author{
Miimu Airaksinen, Jarek Kurnitski, and Olli Seppänen \\ HVAC Laboratory, Helsinki University of Technology, P.O. Box 4400, FIN-02015 HUT, Finland; \\ jarek.kurnitski@hut.fi
}

Received 5 December 2002, in revised form 24 January 2003

\begin{abstract}
This study considers transient effects of the moisture capacity and other properties of ground covers and base floor on relative humidity in cold-climate outdoor-air-ventilated crawl spaces. The objectives of the study were to find out how relative humidity can be reduced by optimal selection of ground covers and air change rates, and to evaluate the acceptability of achieved moisture conditions by means of mould growth analyses. Two buildings, one with a relatively warm and another with a relatively cold crawl space, were studied with the resistancecapacity network model including the heat and moisture transfer in crawl spaces. Thermal and moisture buffering effects of various ground covers and air change rates were simulated. In a relatively warm crawl space the moisture problems were easy to avoid - all ground covers gave clearly acceptable conditions at an air change rate of 0.5-2.0 ach. In the cold crawl space, the moisture conditions were much more critical. The acceptability of conditions was evaluated by calculating the mould growth index. To achieve acceptable moisture conditions, $15-30 \mathrm{~cm}$ lightweight expanded clay aggregate or 5-10 cm expanded polystyrene ground cover must be used. An air change rate of $0.5-1.0$ ach provided the lowest relative humidity conditions during the heating season, and in the summer it was necessary to use an air change rate of 2.0-5.0 ach to warm up the crawl space. In critical conditions, thermal insulation and moisture capacity proved to be important properties of the ground cover allowing to achieve acceptable conditions.
\end{abstract}

Key words: crawl space, air change rate, relative humidity, mould growth.

\section{INTRODUCTION}

A typical Finnish building foundation is a crawl space construction. Recently, many moisture and mould damages have been reported especially in crawl spaces. It is well known that the behaviour of a crawl space becomes problematic particularly in the summer: in the daytime outdoor air is warmer and has a higher moisture content than the crawl space air. When air is cooled down in the crawl 
space, relative humidity (RH) and the risk of condensation increases. There is always a risk of mould growth if $\mathrm{RH}$ is over $75 \%$ and the temperature is in the range of $5-35^{\circ} \mathrm{C}\left[{ }^{1-3}\right]$.

Although there is always a risk of mould growth at a high $\mathrm{RH}$ level, it can be accepted during short periods. The risk of mould growth is negligible if the humid period is shorter than the time needed to start mould growth. The time needed for harmful mould growth does not only depend on time, temperature, $\mathrm{RH}$, and air change, but is strongly dependent on the contamination of the material surface (usually dust, which consists of a great amount of nutrition). In $\left.{ }^{4,5}\right]$, mould growth has been estimated by means of a risk factor having values from $0-1$. This factor is a function of temperature and $\mathrm{RH}$, but the impact time has not been taken into account. In this study, an equation that gives an exact value for the current state of the mould growth is used. This equation applies for wood (only for pine and spruce), and is a function of temperature and $\mathrm{RH}\left[{ }^{6,7}\right]$ :

$$
\frac{\mathrm{d} M}{\mathrm{~d} t}=\frac{1}{7 \cdot \exp (-0.68 \ln T-13.9 \ln \varphi+0.14 W-0.33 S Q+66.02)} .
$$

Here $M$ is the mould growth index, $T$ is temperature $\left(0.1-40^{\circ} \mathrm{C}\right), \varphi$ is relative humidity given in percents, $W$ specifies the wood - for pine $W=0$ and for spruce $W=1$, and $S Q$ is a factor describing the quality of the wood surface (for a resawed surface after drying $S Q=0$, for a kiln-dried surface $S Q=1$ ). When conditions become unfavourable, the mould growth will slow down and $M$ will decrease. The delay of the mould growth caused by low RH (below the critical value) is given as

$$
\frac{\mathrm{d} M}{\mathrm{~d} t}=\left\{\begin{array}{cl}
-0.032, \text { when } & t-t_{1} \leq 6 \mathrm{~h}, \\
0, & 6<t-t_{1} \leq 24 \mathrm{~h}, \\
-0.016, & t-t_{1}>24 \mathrm{~h} .
\end{array}\right.
$$

Here, $t-t_{1}$ is the number of days from the beginning of the dry period. In this study the critical value for $\mathrm{RH}$ is considered to be either 75,80 , or $85 \%$.

Equation (2) estimates mould growth with the mould growth index $M$, which can vary between 0 and 6 . The value $M=0$ indicates no mould growth; $M=1-$ some growth detected with microscope, $M=3$ - some mould detected visually, and $M=6$ - very heavy and dense mould growth, covering nearly $100 \%$ of the surface. In this study, $M=1$ is used as a criterion for mould growth. There is no direct microbial basis for the criterion, but this is the first stage of mould growth which can be detected by the microscope.

In favourable conditions $\left(\varphi \approx 95 \%, T=20^{\circ} \mathrm{C}\right)$, Eq. (1) gives about two weeks for mould growth to reach $M=1$ in pine. If $\mathrm{RH}$ is decreased to $75 \%$, the time needed for mould growth to start is increased to 38 weeks $\left[{ }^{3,8}\right]$.

This study discusses the effects of moisture capacity and other properties of ground covers and base floor on relative humidity in an outdoor-air-ventilated crawl space in a cold climate. The objectives were to find out how relative 
humidity can be reduced by optimal selection of ground covers and air change rates, and to evaluate the acceptability of achieved moisture conditions by carrying out mould growth analyses. The first building studied was a typical apartment building with a relatively warm crawl space (high thermal transmittance coefficient $U$ of the base floor). The second building was a wooden day-care centre with a highly insulated base floor and a relatively cold crawl space. Parametric simulations, in which the thickness of ground covers and air change rates were varied, were carried out for several ground covers in these buildings. The acceptability of the moisture conditions in the crawl space was evaluated by calculating the mould growth index.

\section{METHOD}

The measurements of $\mathrm{RH}$, temperature, and air change rate were carried out in the two test buildings. The measured crawl spaces are completely different in respect of their heat and moisture behaviour. The first building was a typical 20-year-old, 4-storey apartment building, built from sandwich elements. The crawl space of that building was relatively warm due to the high thermal transmittance coefficient of the base floor $\left(U=0.38 \mathrm{~W} \mathrm{~m}^{-2} \mathrm{~K}^{-1}\right)$. The second building was an 11-year-old one-storey wooden day-care centre, which represents building technology used in detached houses. The crawl space of that building was rather cold due to a highly insulated base floor $\left(U=0.2 \mathrm{~W} \mathrm{~m}^{-2} \mathrm{~K}^{-1}\right)$.

The simulations were carried out in an IDA simulation environment $\left[{ }^{9}\right]$, where the resistance-capacity (RC) network model was used. IDA is a modular simulation environment which consists of a translator, solver, and modeller. The solver and physical models are separated which makes it possible to change the mathematical formula of any component without changing the model description file. The modules are written in Neural Model Format which serves at the same time as a readable document and a computer code. Via the translator, the modules can be used in several modular simulation environments $\left[{ }^{10,11}\right]$. The heat transfer equations are the same as reported in $\left[{ }^{12}\right]$ but the moisture transfer model has been improved. The model takes into account the heat transfer in structures and ground (conduction, convection, and radiation only between the ground and base floor) as well as heat and moisture flows carried by ventilation.

The conduction in the ground soil is modelled by means of semicircular heat flow patterns, "Ground1", "Ground2", and "Wall1", as shown in Fig. 1. The floor area of the crawl space is divided into two parts: the first meter along the external walls (Ground 1) and the remainder (Ground 2). In the warm crawl space of an apartment building, an adiabatic wall was used to model the foundation beam dividing the crawl space into two parts (Fig. 1). The ground surface in the modelled colder crawl space was covered by expanded clay aggregate (Fig. 2). The main components of the crawl space RC-network are shown in Fig. 3 (the adiabatic wall used in modelling the warm crawl space is not shown). 

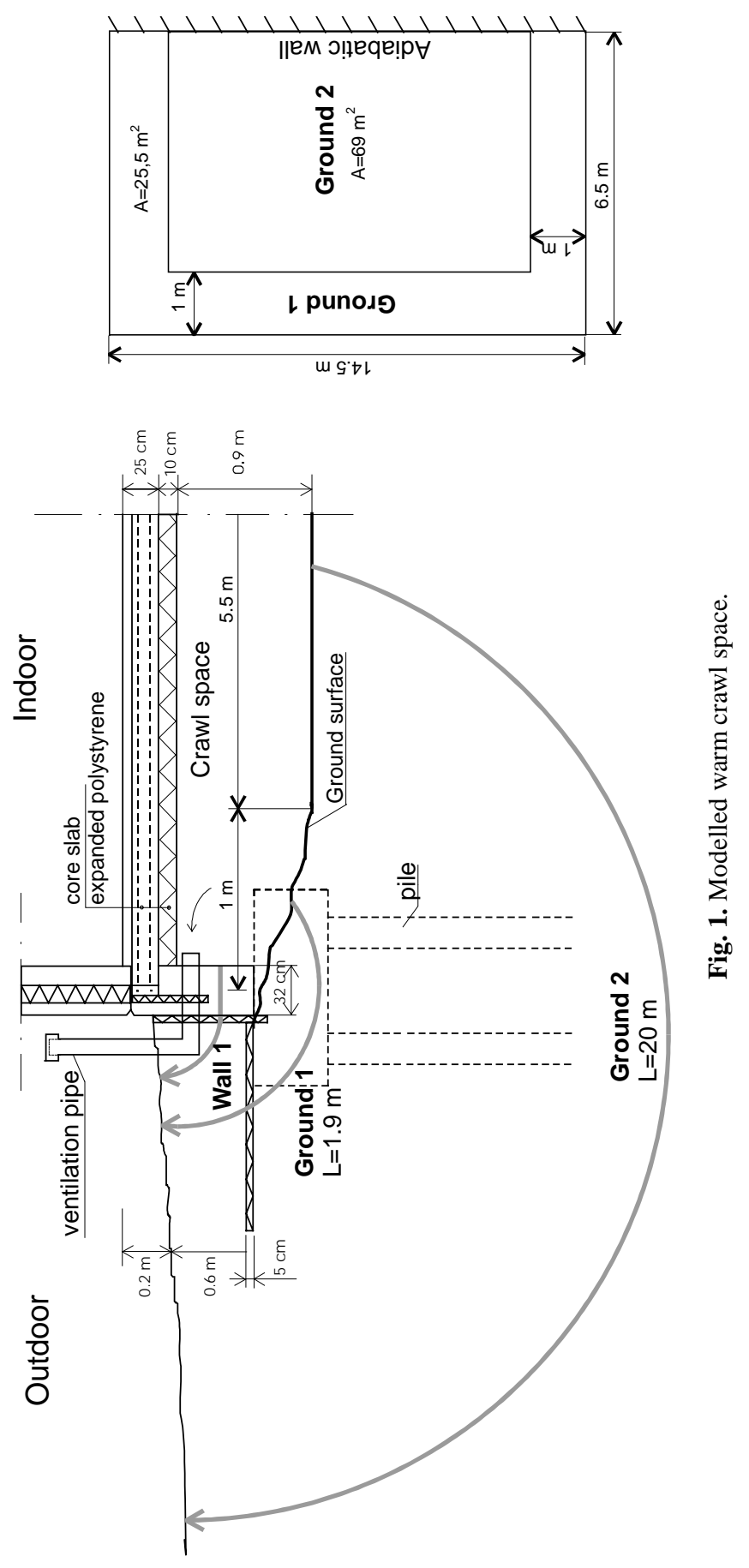


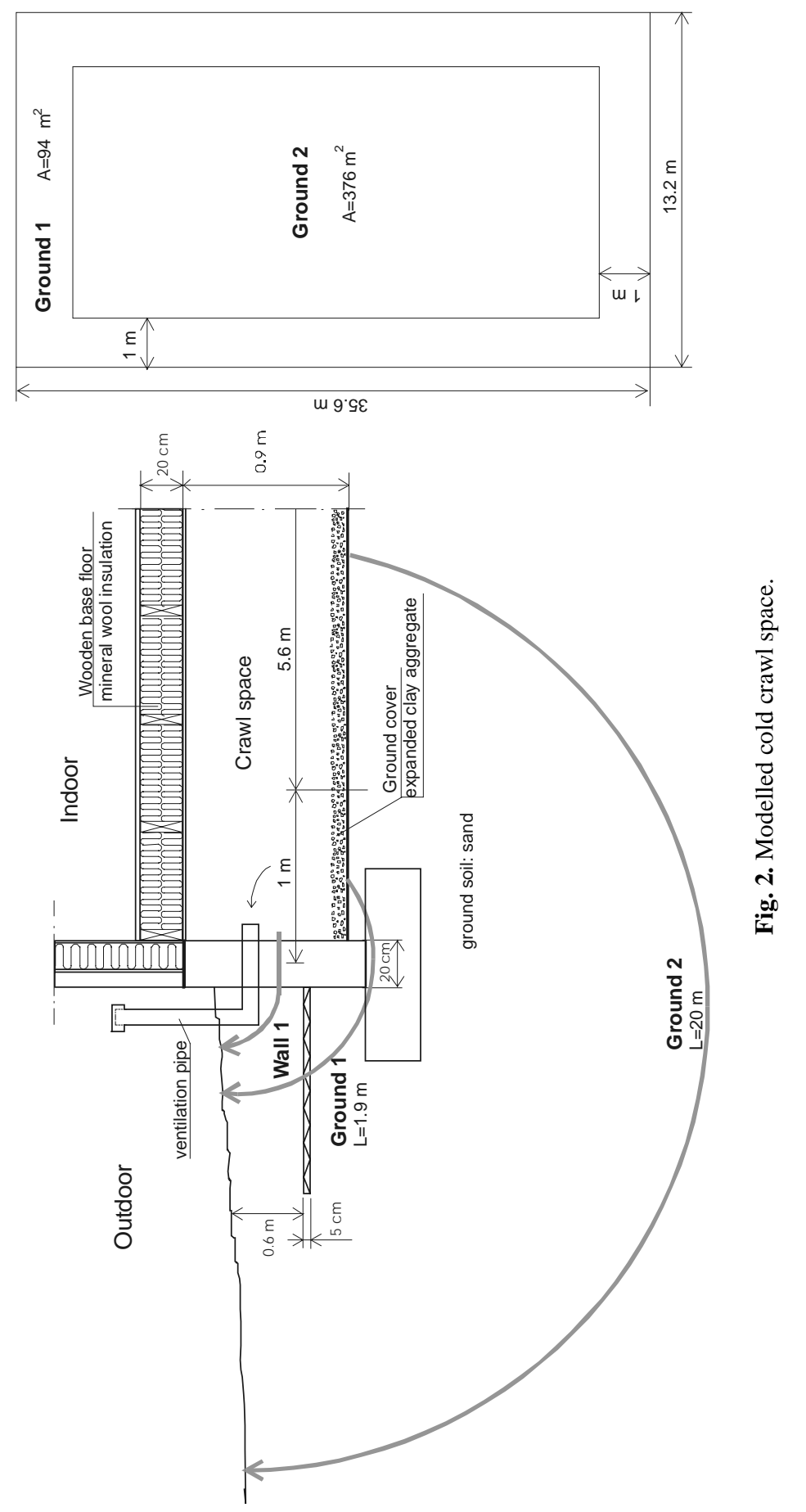




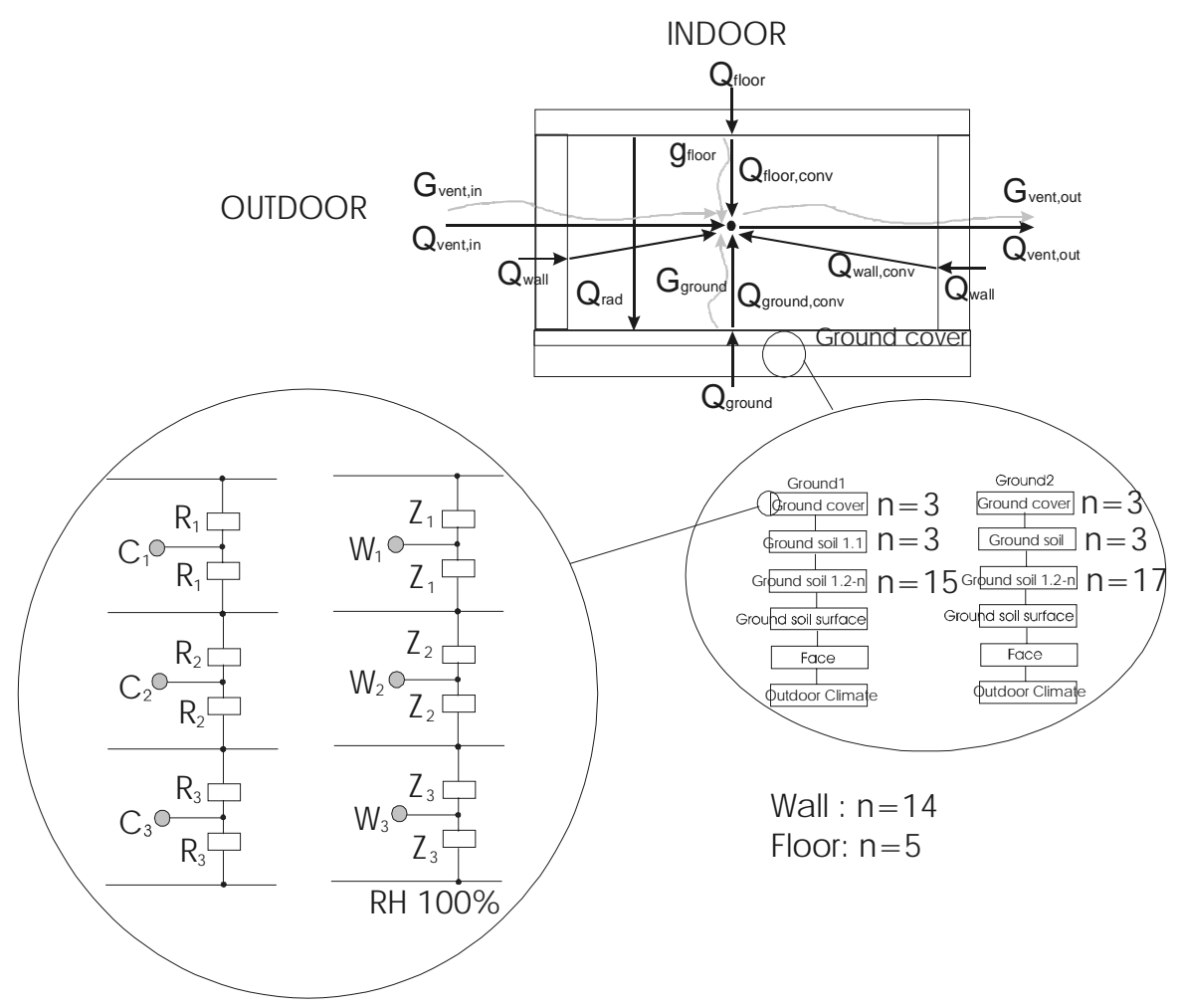

Fig. 3. RC-network model of the crawl space: $\mathrm{Q}$ - heat flow, g-moisture flow, W-moisture content by volume, $\mathrm{Z}$ - diffusive moisture resistance, $\mathrm{C}$ - volumetric heat capacity, $\mathrm{R}$ - thermal resistance, $\mathrm{n}$ - number of calculated nodes.

Moisture transfer includes evaporation from the ground, and moisture transfer in the base floor and in the ground cover. Therefore it was possible to take the moisture capacity of the base floor and ground cover into account. Humidity by volume is used as the transfer potential. A detailed description of the moisture model can be found in $\left[{ }^{12}\right]$. The moisture balance equation for the crawl space air is

$$
V \frac{\partial \rho_{\mathrm{w}}}{\partial t}=\left(x_{\text {out }}-x\right) q_{\mathrm{m}}+g_{\text {ground }}+g_{\text {floor }},
$$

where $V$ is the volume of the crawl space $\left[\mathrm{m}^{3}\right], \rho_{\mathrm{w}}$ is humidity by volume $\left[\mathrm{kg} \mathrm{m}^{-3}\right], t$ is time $[\mathrm{s}], x$ is the absolute humidity in the crawl space $\left[\mathrm{kg} \mathrm{kg}^{-1}\right]$, $x_{\text {out }}$ is the outdoor absolute humidity $\left[\mathrm{kg} \mathrm{kg}^{-1}\right], q_{\mathrm{m}}$ is the air change rate in the crawl space $\left[\mathrm{kg} \mathrm{s}^{-1}\right]$, and $g$ is the moisture flow of evaporation from ground and base floor surfaces $\left[\mathrm{kg} \mathrm{s}^{-1}\right]$.

Moisture transfer in the ground cover and base floor was calculated with a HAMWall-module $\left[{ }^{13}\right]$. The moisture flow and balance equations are the following: 


$$
\begin{aligned}
& g^{\prime \prime}=-\delta_{\mathrm{v}} \frac{\partial \rho_{\mathrm{w}}}{\partial x}, \\
& \frac{\partial w}{\partial t}=-\frac{\partial g^{\prime \prime}}{\partial x},
\end{aligned}
$$

where $g^{\prime \prime}$ is the moisture flow $\left[\mathrm{kg} \mathrm{s}^{-1} \mathrm{~m}^{-2}\right], \quad \delta_{\mathrm{v}}$ is the moisture permeability $\left[\mathrm{m}^{2} \mathrm{~s}^{-1}\right], w$ is the moisture content of the material $\left[\mathrm{kg} \mathrm{m}^{-3}\right]$, and $x$ is the depth $[\mathrm{m}]$.

Under the ground cover, a boundary condition of $\rho_{\mathrm{w}}$, corresponding to $\varphi=100 \%$, is used. The moisture transport is not calculated in the ground soil and foundations. The sorption isotherms are modelled linearly using two points: the moisture content $w_{1}$ and $\varphi_{1}$ at the inflection point, and $w_{2}$ at $\varphi=100 \%$.

The moisture capacity was not taken into account in some of the calculations to demonstrate its effect. In these cases the steady state form of Eq. (4) was used:

$$
g_{\text {ground }}=\frac{\rho_{\mathrm{w}, \text { ground }}-\rho_{\mathrm{w}, \text { air }}}{d / \delta_{\mathrm{v}}} A_{\text {eva }}
$$

where $\rho_{\mathrm{w}, \text { ground }}$ is the humidity by volume on the ground surface $\left[\mathrm{kg} \mathrm{m}^{-3}\right], \rho_{\mathrm{w}, \text { air }}$ is the air humidity by volume $\left[\mathrm{kg} \mathrm{m}^{-3}\right], d$ is the thickness of the ground cover $[\mathrm{m}]$ and $A_{\text {eva }}$ the area of the evaporating surface $\left[\mathrm{m}^{2}\right]$.

In the cases of uncovered ground, the ground moisture evaporation was calculated as

$$
g_{\text {ground }}=\beta\left(\rho_{\mathrm{w}, \text { ground }}-\rho_{\mathrm{w}, \text { air }}\right) A_{\text {eva }},
$$

where $\beta$ is the mass transfer coefficient $\left[\mathrm{m} \mathrm{s}^{-1}\right]$ and $\rho_{\text {w,air }}$ is the crawl space air humidity by volume $\left[\mathrm{kg} \mathrm{m}^{-3}\right]$. Humidity by volume is $\rho=x \rho_{\text {air }}$, where $\rho_{\text {air }}$ is the density of air $\left[\mathrm{kg} \mathrm{m}^{-3}\right]$. To determine the mass transfer coefficient, the convective heat transfer is assumed $\left[{ }^{14}\right]$. The so-called Lewis relation, used in $\left[{ }^{12}\right]$, gives

$$
\beta=\frac{\alpha}{\rho_{\mathrm{w}, \mathrm{air}} c_{\mathrm{p}}},
$$

where $\alpha$ is the convective heat transfer coefficient $\left[\mathrm{W} \mathrm{m}^{-2} \mathrm{~K}^{-1}\right]$ and $c_{\mathrm{p}}$ is the air heat capacity $\left[\mathrm{J} \mathrm{kg}^{-1} \mathrm{~K}^{-1}\right]$. Typical values for $\beta$ are $0.0012 \mathrm{~m} / \mathrm{s}$ for naturally ventilated crawl spaces and $0.0018 \mathrm{~m} \mathrm{~s}^{-1}$ for mechanically ventilated crawl spaces $\left[{ }^{15}\right]$.

The convective heat transfer coefficient for uncovered ground was calculated from temperature differences with the equation recommended for high air change rates in $\left[{ }^{15}\right]$ :

$$
\alpha=2.2\left(T_{\text {ground }}-T_{\text {air }}\right)^{1 / 3}+4 v,
$$

where $v$ is the air velocity $\left[\mathrm{m} \mathrm{s}^{-1}\right]$. Air velocity was calculated from air change rate equation $\left[{ }^{15}\right]$ 


$$
4 v=5.4 q_{\mathrm{v}},
$$

where $q_{\mathrm{v}}$ is the air flow in the crawl space $\left[\mathrm{m}^{3} \mathrm{~s}^{-1}\right]$. Typical values for $\alpha$ are $1.56 \mathrm{~W} \mathrm{~m}^{-2} \mathrm{~K}^{-1}$ for naturally ventilated crawl spaces and $2.26 \mathrm{~W} \mathrm{~m}^{-2} \mathrm{~K}^{-1}$ for the mechanically ventilated ones. For other surfaces, constant convective heat transfer coefficients were used; for walls (foundations) $\alpha=4.6 \mathrm{~W} \mathrm{~m}^{-2} \mathrm{~K}^{-1}$ and for base floor $\alpha=2.3 \mathrm{~W} \mathrm{~m}^{-2} \mathrm{~K}^{-1}$.

\section{VALIDATION OF THE SIMULATION MODEL}

Calculations were carried out using three different assumptions in the model. In the first version, no moisture capacities were taken into account. Here, the balance equation (2) and the evaporation equation (6) were used. In the second version, the moisture capacity of the ground cover and in the third one, the moisture capacities of the ground cover and base floor were taken into account. The moisture capacity of foundations were not taken into account since they are made of concrete, which has a low moisture capacity. Also, the area of foundations is relatively small as compared to the area of the base floor. The moisture capacity of the ground soil was not considered because the constant value of $\varphi=100 \%$ was used below the ground cover.

Parameter identification was carried out for the thermal conductivity and capacity of the ground soil and for the value of $U$ of the base floor. The latter was necessary due to a cold bridge in the joint of the base floor and the foundation beam (Fig. 1). The other material properties used were obtained from the manufacturers of the materials. The properties used for ground soil in Table 1 are typical for Finland. The measured data of a six-month period was used for the parameter identification. The measured outdoor temperature and $\mathrm{RH}$ were used as boundary conditions for the model. Approximate values of the air change rate are used in both buildings. In the cold crawl space of the wooden building the

Table 1. Material properties used in calculations

\begin{tabular}{l|c|c|c|c|c|c}
\hline \multicolumn{1}{c|}{ Property } & $\begin{array}{c}\text { Ground } \\
\text { soil } \\
\text { (mixed } \\
\text { clay) }\end{array}$ & $\begin{array}{c}\text { Ground } \\
\text { soil } \\
\text { (sand) }\end{array}$ & Concrete & $\begin{array}{c}\text { Mineral } \\
\text { wool }\end{array}$ & EPS & LWA \\
\hline Thermal conductivity, $\mathrm{W} \mathrm{m}^{-1} \mathrm{~K}^{-1}$ & 1.6 & 1.7 & 1.2 & 0.03 & 0.04 & 0.12 \\
Specific heat capacity, $\mathrm{J} \mathrm{kg}^{-1} \mathrm{~K}^{-1}$ & 1800 & 2300 & 880 & 750 & 900 & 950 \\
Volume weight, $\mathrm{kg} \mathrm{m}^{-3}$ & 1600 & 2000 & 2300 & 17 & 20 & 250 \\
Moisture permeability, $\mathrm{m} \mathrm{s}^{-1}$ & & & $3.0 \times 10^{-7}$ & $18.0 \times 10^{-6}$ & $1.0 \times 10^{-6}$ & $1.7 \times 10^{-5}$ \\
Sorption isotherm & & & $75 ; 80$ & $0.2 ; 25$ & $0.2 ; 85$ & $1.0 ; 94$ \\
1st point $\left(w_{1}, \mathrm{~kg} \mathrm{~m}^{-3} ; \varphi_{1}, \%\right)$ & & 100 & 0.35 & 0.6 & 2.0 \\
2nd point $\left(w_{2}, \mathrm{~kg} \mathrm{~m}^{-3} ; \varphi_{2}=100 \%\right)$ & & & & &
\end{tabular}

EPS - expanded polystyrene insulation, LWA - light-weight clay aggregate. 
measured air flow of the exhaust fan of the crawl space was used. In the warm crawl space of the apartment building, an average air change rate of a threemonth measurement period with natural ventilation was used. The final values of the ground thermal conductivity and volume weight were identified by using the measured data from the test building. The parameters used in the calculations are shown in Table 1, and the description of the buildings in Table 2.

Because no significant differences in the crawl space temperatures, computed with the second and third model, were found, only the results of the third version are shown in Fig. 4. In the cold crawl space, the calculated temperature was slightly lower when the capacities were not taken into account, and in the warm crawl space moisture capacity had no effect (not shown in Fig. 4). In the winter, during the two last weeks of February, the outdoor air sensors were covered by snow which explains some disagreement between calculated and measured temperatures during this period (calculated $T$ and $\varphi$ are somewhat higher). The cold crawl space of the wooden building was much colder compared to the warm

Table 2. Description of the construction

\begin{tabular}{l|l|l}
\hline & \multicolumn{1}{c|}{ Warm crawl space } & \multicolumn{1}{c}{ Cold crawl space } \\
\hline Ground soil & Clay & Sand \\
Ground cover & $17 \mathrm{~cm}$ light-weight aggregate & $15 \mathrm{~cm}$ light-weight aggregate \\
Base floor & Hollow-core concrete slab, & Wooden construction, \\
& $\begin{array}{l}10 \mathrm{~cm} \text { expanded polystyrene attached under } \\
\text { the slab }\end{array}$ &
\end{tabular}

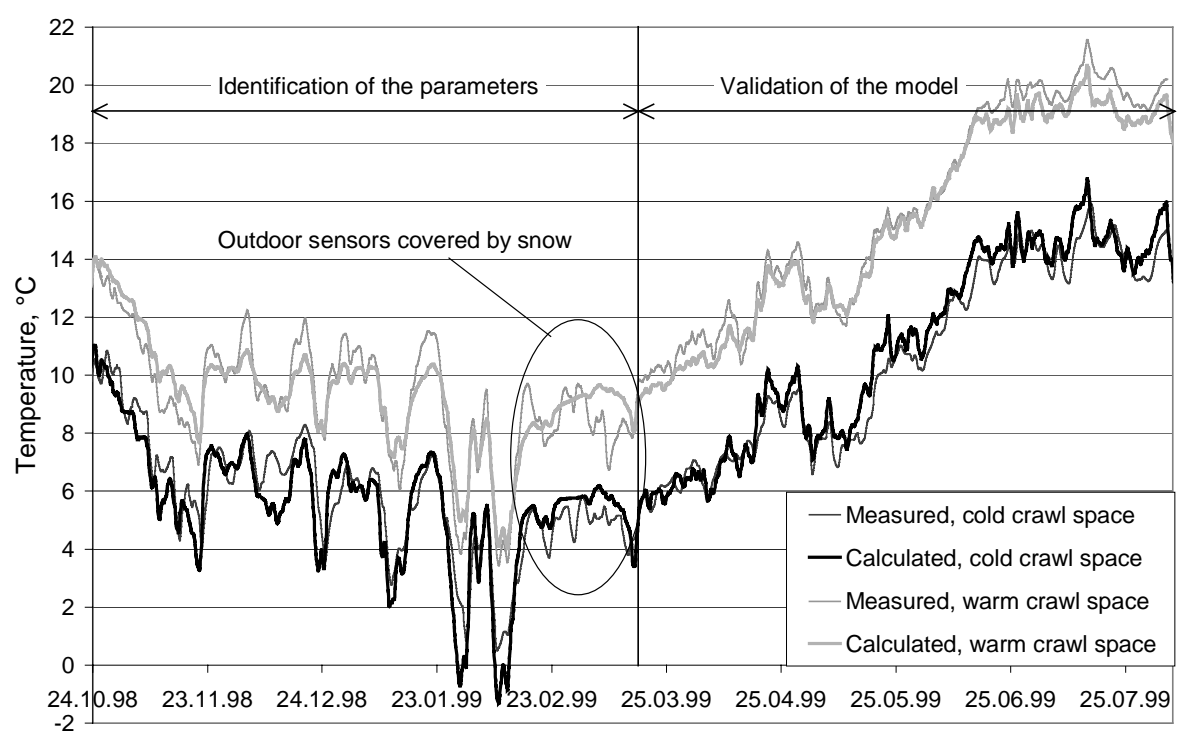

Fig. 4. Calculated and measured temperatures in the crawl spaces. The air change rate in both calculations is 1.1 ach (24-hour moving averages). 
crawl space of the apartment building. The maximum air temperature in the crawl space during the measured year (1998-1999) was $17^{\circ} \mathrm{C}$ and during a few periods in the winter, the temperature in the crawl space was some degrees below zero.

Relative humidity in the warm and cold buildings is shown in Figs. 5 and 6. In the warm crawl space, the expanded polystyrene (EPS) insulation in the base floor did not affect RH, but light-weight clay aggregate (LWA) slightly reduced $\mathrm{RH}$ fluctuations. The effect of moisture capacity was remarkable in the cold crawl space. Relative humidity, calculated for the first model (no moisture capacity), fluctuated far too much. In the winter, the calculated RH was too low, and in the summer condensation occurred. Both LWA and the base floor affected $\mathrm{RH}$, and the most accurate result was obtained with the third model (both moisture capacities taken into account). Similarly, moisture capacity had an effect on mould growth index. In fact, the influence was much stronger than would be expected based on the RH measurement results.

The absolute value of the difference between the measured and calculated values (absolute difference) in the cold crawl space is highest in the case when the moisture capacity is not taken into account (Fig. 7), average difference being $15 \%$. In the case when moisture capacity in the LWA ground cover is taken into account, the average difference is $10 \%$ and if also the moisture capacity in the base floor is taken into account, the average difference is $8 \%$.

RH inside the LWA layer, which was measured at the beginning of December 1998, was possible to predict with the third model (moisture transfer in the ground cover and in the base floor was taken into account, Fig. 8). Some disagreement between the calculated and measured relative humidities can be explained by the simplified heat conduction calculation in the ground soil.

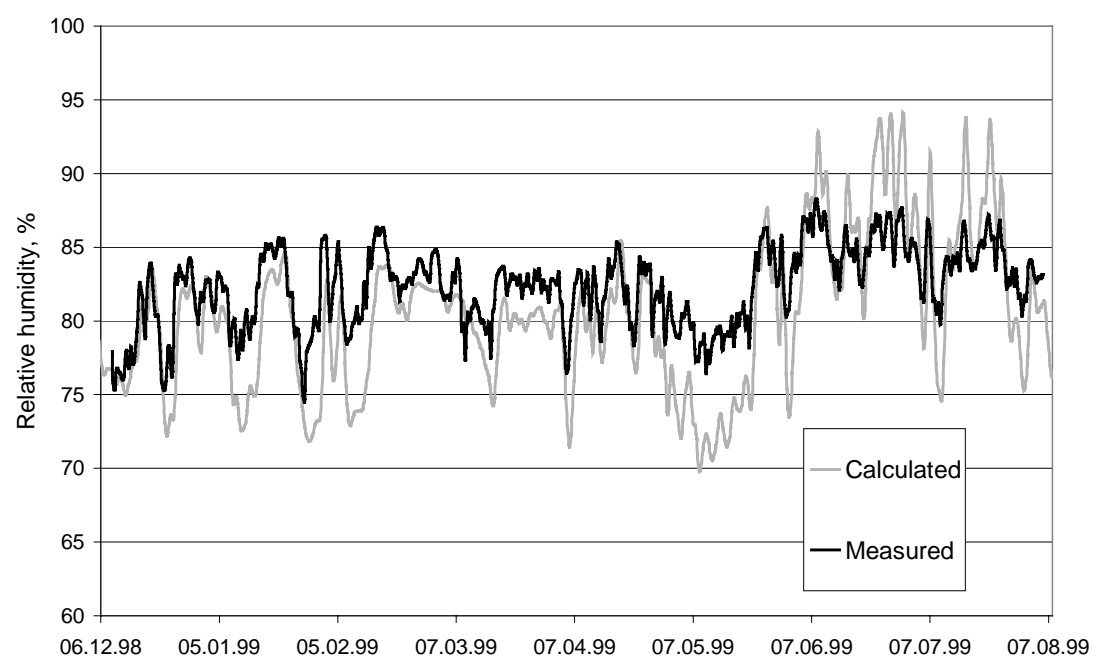

Fig. 8. Measured and calculated RH in the middle of the LWA layer in the cold crawl space. 


\section{THE EFFECT OF THE AIR CHANGE RATE ON THE TEMPERATURE AND RELATIVE HUMIDITY IN THE CRAWL SPACE}

Temperatures and RH were calculated for various air change rates. In both crawl spaces an LWA ground cover was applied, and the moisture transfer in LWA and in the base floor was taken into account. To assess the mould growth risk, mould growth index $M$ was calculated. Three critical values of $\varphi$ are considered: 75,80 , and $85 \%$.

The air change rate in a crawl space affects both thermal and moisture behaviour but it does not affect much the ground moisture evaporation when a ground cover is applied. The average moisture evaporation through the LWA cover was $0.72 \mathrm{~g} \mathrm{~h}^{-1} \mathrm{~m}^{-2}$ in the cold crawl space and $0.92 \mathrm{~g} \mathrm{~h}^{-1} \mathrm{~m}^{-2}$ in the warm one. Due to thermal behaviour, the optimum air change rates in the summer and winter are different. In practice, air change rates of $0.5-1.0$ ach are commonly used, but in our calculations air change rates up to 5.0 ach are studied.

\subsection{The warm crawl space}

The effect of the air change rate on crawl space conditions is shown in Fig. 9. A high air change rate cools down the crawl space in the winter and warms it slightly up in the summer, Fig. 9 (left). The lowest RH in the crawl space is achieved when the air change rate during the heating season is $0.2-1.0$ ach (Fig. 9, right). High air change rates increase RH during the heating season. In the summer, RH is not sensitive to the air change rate due to a relatively warm crawl space ( $U$ of the base floor is high). This can be seen from the calculated mould growth index $M$ (Table 3). Mould growth index was calculated during the whole year, and the critical $\mathrm{RH}\left(\varphi_{\mathrm{cr}}\right)$ was assumed to be $75 \%$. In the calculations it is assumed that the wood is pine and the surface is not sawed after drying $(W=0, S Q=1)$.

Table 3. Maximum value of the mould growth index $M$ for various air change rates for the warm and cold crawl space ( $h$ - thickness of the LWA cover)

\begin{tabular}{l|c|c|c|c}
\hline \multirow{2}{*}{$\begin{array}{c}\text { Air change rate, } \\
\text { ach }\end{array}$} & $\begin{array}{c}\text { Warm crawl space, } \\
h=17 \mathrm{~cm}\end{array}$ & \multicolumn{3}{|c}{$\begin{array}{c}\text { Cold crawl space, } \\
h=15 \mathrm{~cm}\end{array}$} \\
\cline { 2 - 5 } & \multicolumn{4}{|c}{$\varphi_{\text {cr }}, \%$} \\
\cline { 2 - 5 } & 75 & 75 & 80 & 85 \\
\hline 0.2 & 0.01 & - & - & - \\
0.5 & 0.01 & 0.95 & 0.52 & 0.07 \\
1.0 & 0.02 & 1.14 & 0.70 & 0.33 \\
2.0 & 0.05 & 1.20 & 0.79 & 0.47 \\
$2.0-0.5^{*}$ & - & 0.82 & 0.58 & 0.35 \\
5.0 & 0.15 & 1.29 & 1.08 & 0.72 \\
$5.0-0.5^{*}$ & - & 0.70 & 0.47 & 0.31
\end{tabular}

\footnotetext{
* The higher air change rate is used in the summer, 0.5 ach between Oct 1st and Apr 30th
} 
The moisture content in the LWA cover is rather stable throughout the year due to a warm and relatively dry crawl space (Fig. 10). Slightly increased values can be seen in the summer.

\subsection{The cold crawl space}

The crawl space of the wooden day-care centre was relatively cold throughout the year. High air change rates warm the crawl space up in the summer (Fig. 11, left). In the case of higher air change rates (2.0 and $5.0 \mathrm{ach})$, a two-step air change rate was used (2.0 or 5.0 ach in the summer from May 1 to September 30, and 0.5 ach in the cold season). The results were almost the same when the air change was reduced from October 1 to May 31 . RH is clearly higher than in the cold crawl space (Fig. 11, right), exceeding 75\% at the end of May. Highest air change rate 5 ach gives the lowest RH in the summer. Still, even in this case $M$ is close to the critical value $1 ; M$ is calculated for relative humidities 75,80 , and $85 \%$ (Table 3 ). In the calculations it is assumed that the wood is pine and the surface is not sawed after drying $(W=0, S Q=1)$.

The behaviour of the moisture content curve of LWA shows its capability to reduce RH fluctuation (Fig. 12). In the summer, when the outdoor air becomes a source of humidity, the LWA cover stores moisture into itself.

\subsection{The effect of weather data}

The weather data used in the calculations significantly affects the results. In Fig. 13, the Finnish test-year for energy calculations $\left[{ }^{16}\right]$, which was modified in year 1979, was used. That year had an exceptionally cold and moist summer, and $\mathrm{RH}$ was near or over $90 \%$ during long periods. Although the temperature is low, mould growth index exceeds 1 during all the period; thus mould growth starts (Table 4). The weather of 1998 was considered to be more typical and it was used in other calculations. In 1998, the higher air change rates decreased relative humidity in the crawl space in the summer, but when the weather data of the testyear was used, a higher air change rate did not give any advantage. Even outdoor conditions $\left(T_{\text {ave }}=10.4^{\circ} \mathrm{C}, \varphi_{\text {ave }}=82.5 \%\right)$ give favourable conditions for mould growth. Although this does not ensure mould growth (because it depends on the temperature, RH, and time according to Eq. (1)), it indicates a very high risk for mould growth on any wood in contact with outdoor air, also in crawl spaces.

Table 4. Mould growth index for various air change rates when weather data of 1979 is used, $\varphi_{\mathrm{cr}},=75 \%$

\begin{tabular}{cc}
\hline Air change rate, ach & $M$ \\
\hline 0.5 & 1.63 \\
1.0 & 2.13 \\
2.0 & 2.57 \\
5.0 & 2.70
\end{tabular}




\section{THE EFFECT OF GROUND COVERS IN THE CRAWL SPACE}

Ground covers may have an effect in two ways: they reduce the moisture evaporation from the ground and, on the other hand, they may act as thermal insulation. The calculations were made for four cases: a $15 \mathrm{~cm}$ LWA cover, a $5 \mathrm{~cm}$ EPS thermal insulation, a PVC sheet, and an uncovered ground. In addition, a $30 \mathrm{~cm}$ LWA cover was simulated for the cold crawl space.

\subsection{The warm crawl space}

The effect of ground covers on the crawl space temperature, when an air change rate of 0.5 ach is used, is shown in Fig. 14, left. The highest temperature was achieved with EPS and LWA covers, due to their thermal insulation. The lowest temperature was reached with uncovered clay ground which has the highest evaporation rate of $1.7 \mathrm{~g} \mathrm{~h}^{-1} \mathrm{~m}^{-2}$ (the model calculates the heat of evaporation). The PVC cover blocks evaporation completely in the calculations and therefore the crawl space is warmer compared to the uncovered clay ground. Although $0.94 \mathrm{~g} \mathrm{~h}^{-1} \mathrm{~m}^{-2}$ of moisture evaporates through a $15 \mathrm{~cm} \mathrm{LWA} \mathrm{cover,} \mathrm{and}$ only $0.29 \mathrm{~g} \mathrm{~h}^{-1} \mathrm{~m}^{-2}$ evaporates through a $5 \mathrm{~cm}$ EPS insulation cover, the temperatures in the crawl space are almost the same. This is caused by their equal thermal resistances $\left(1.25 \mathrm{~m}^{2} \mathrm{KW}^{-1}\right)$. The highest $\mathrm{RH}$ was reached with an uncovered ground; RH was between 75 and $90 \%$ during the whole year (Fig. 14, right). Due to the moisture capacity, a crawl space with a LWA layer has the most stable RH level during the whole year. However, EPS shows the lowest RH as its moisture resistance is slightly higher in comparison with LWA. With a PVC cover RH in the crawl space fluctuates most. The evaporation rates are shown in Fig. 15. The negative values indicate condensation in the summer. Average RH values are shown in Table 5. Relative humidity is over $75 \%$ only in the case of uncovered ground.

Table 5. Average relative humidity during two-week periods in the summer, \%, for different ground covers

\begin{tabular}{c|c|c|c|c}
\hline \multirow{2}{*}{ Period } & \multicolumn{4}{|c}{ Ground cover } \\
\cline { 2 - 5 } & Clay & LWA & EPS & PVC sheet \\
\hline $06.06-19.06$ & 83.4 & 64.3 & 61.2 & 66.0 \\
$20.06-03.07$ & 85.4 & 67.1 & 65.9 & 71.7 \\
$04.07-17.07$ & 83.1 & 64.4 & 61.6 & 65.4 \\
$18.07-31.07$ & 81.3 & 63.0 & 57.7 & 57.7 \\
$01.08-14.08$ & 82.9 & 64.6 & 58.9 & 58.8
\end{tabular}




\subsection{The cold crawl space}

In the colder crawl space, a higher air change rate of 2.0 ach was used in the calculations to raise the crawl space temperature in the summer. With a PVC cover or uncovered sand in the crawl space, the temperature was significantly lower in the summer compared to the temperature with LWA and EPS covers (Fig. 16, left). With uncovered moist sand, the crawl space has the highest RH, but during the summer a PVC cover shows as high $\mathrm{RH}$ as in the case of uncovered ground (Fig. 16, right). This is caused by the high heat capacity, being the same in both cases. That demonstrates that the outdoor air is the main moisture source during the summer and no evaporation occurs from a cold ground surface (Fig. 17). Negative values indicate significant moisture flow from the air to the ground. In the case of sand, no moisture transfer in the sand was calculated. Only evaporation from the ground surface was calculated and, thus, zero moisture flow may be interpreted as condensation in Fig. 17. The uncovered ground showed the highest average evaporation rate $1.7 \mathrm{~g} \mathrm{~h}^{-1} \mathrm{~m}^{-2}$. Although EPS insulation evaporates far less (on average $0.15 \mathrm{~g} \mathrm{~h}^{-1} \mathrm{~m}^{-2}$ ) than the $15 \mathrm{~cm} \mathrm{LWA}$ cover (on average $0.74 \mathrm{~g} \mathrm{~h}^{-1} \mathrm{~m}^{-2}$ ), there are only small differences in the mould index values (Table 6). The lowest $M$ was reached with a $30 \mathrm{~cm}$ LWA cover. Table 6 shows that in a cold crawl space with a PVC cover or uncovered ground the risk for mould growth is obvious.

In the summer, when outdoor air is the main moisture source, covers store moisture considerably (Fig. 18). The EPS insulation cover can store less moisture than the LWA covers, but its maximal moisture content exceeds even the hygroscopic limit value $0.6 \mathrm{~kg} \mathrm{~m}^{-3}$. The $15 \mathrm{~cm}$ LWA cover nearly reaches its hygroscopic limit value, $2.0 \mathrm{~kg} \mathrm{~m}^{-3}$.

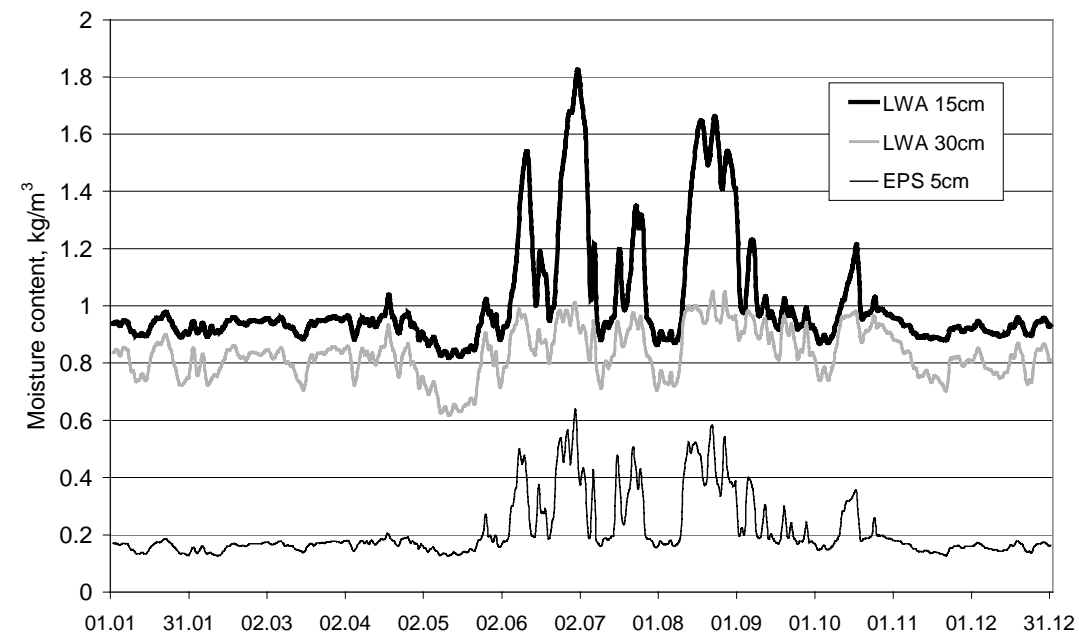

Fig. 18. Moisture content in EPS insulation at $1.7 \mathrm{~cm}$ depth, and in $15 \mathrm{~cm}$ and $30 \mathrm{~cm}$ thick LWA covers at $5 \mathrm{~cm}$ and $10 \mathrm{~cm}$ depth. 
Table 6. Mould growth index $M$ for various ground covers and relative humidities

\begin{tabular}{l|l|l|l}
\hline \multirow{2}{*}{ Ground cover } & \multicolumn{3}{|c}{$\varphi_{\mathrm{cr}}, \%$} \\
\cline { 2 - 4 } & 75 & 80 & 85 \\
\hline Sand & 6 & 6 & 6 \\
LWA $15 \mathrm{~cm}$ & 1.2 & 0.79 & 0.47 \\
LWA $30 \mathrm{~cm}$ & 0.67 & 0.42 & 0.15 \\
EPS & 0.84 & 0.6 & 0.4 \\
PVC sheet & 6 & 6 & 6
\end{tabular}

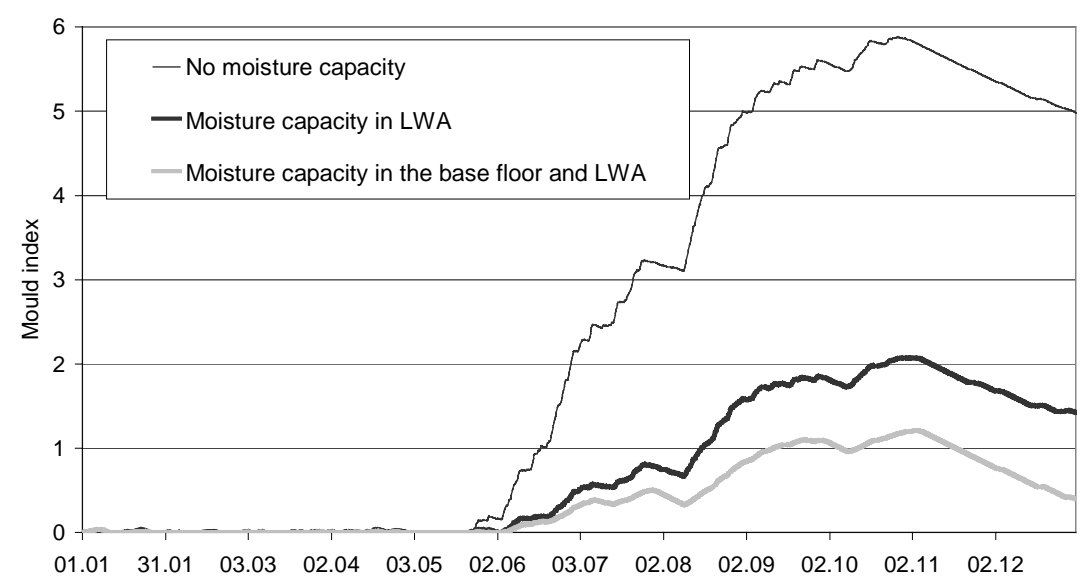

Fig. 19. Mould growth index with $15 \mathrm{~cm}$ LWA cover calculated with and without moisture capacity (air change is $1 \mathrm{ach}, \varphi_{\mathrm{cr}}=75 \%$ ).

The influence of the moisture capacity can be seen in Fig. 19, where the mould growth index is calculated for $15 \mathrm{~cm}$ ground cover in the cases when the moisture capacity is either neglected or taken into account. Neglecting the moisture capacity evidently overestimates the risk of the mould growth.

\section{DISCUSSION}

When the calculated and measured results are compared, some uncertainties in boundary conditions should be taken into account. It was not possible to use exact air change rates, but the air flow rate of the exhaust fan was used as the air change rate in the cold crawl space, and in the warm crawl space the average of a three-month measurement period with natural ventilation was used. Nevertheless, when the calculated temperatures are compared to the measured ones, a reasonably good agreement between the crawl space temperatures can be seen. The deviation is at its maximum $1.5^{\circ} \mathrm{C}$, and usually less than $0.5^{\circ} \mathrm{C}$. It is obvious that the main simplification of the model, the heat transfer in the ground, plays a 


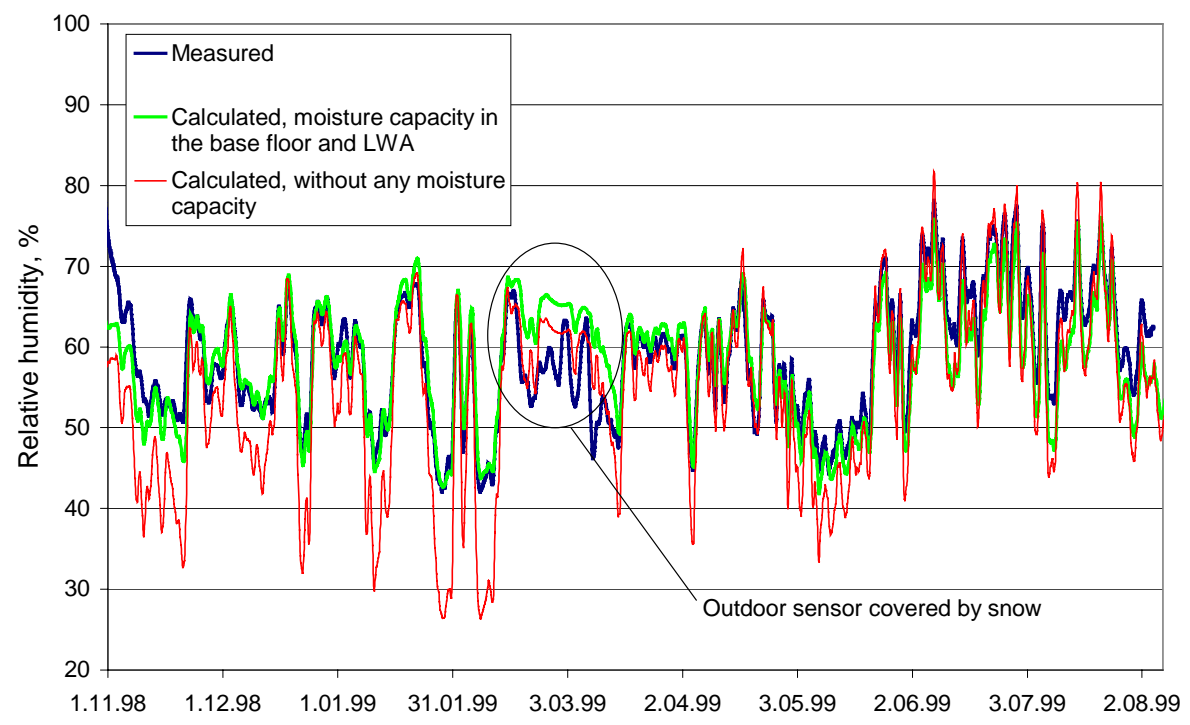

Fig. 5. Calculated and measured relative humidity (24-hour moving averages) in the warm crawl space; air change is 1.1 ach.

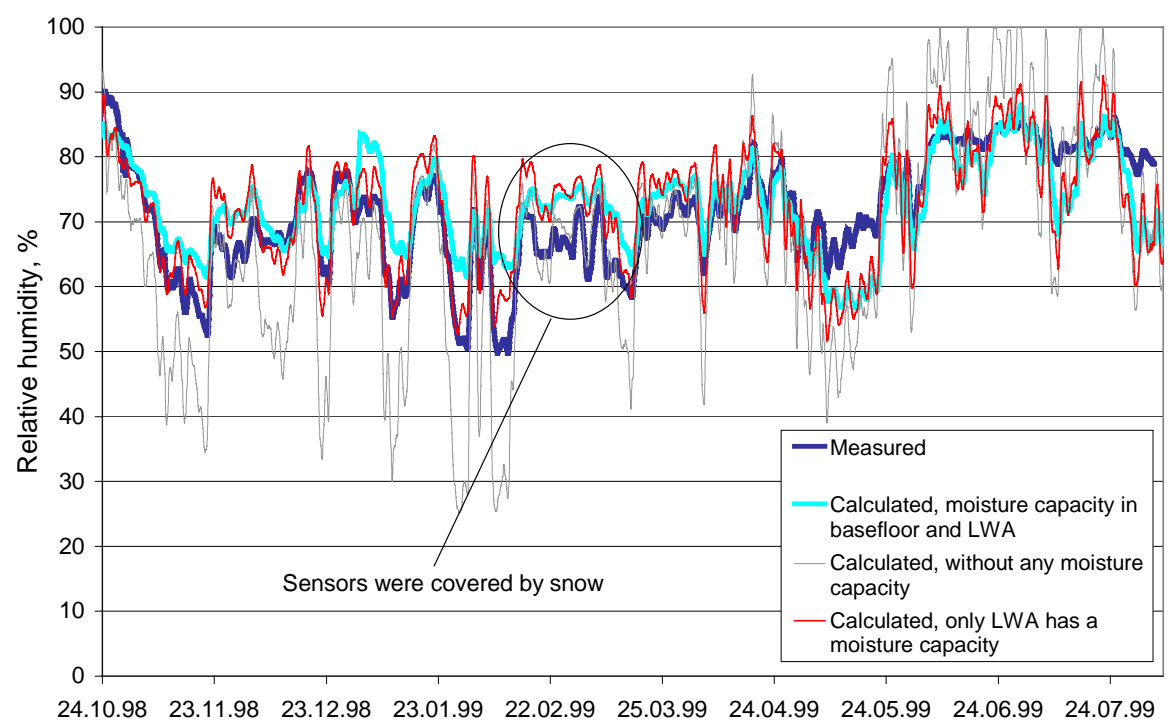

Fig. 6. Calculated and measured relative humidity (24-hour moving averages) in the cold crawl space; air change is 1.1 ach. 


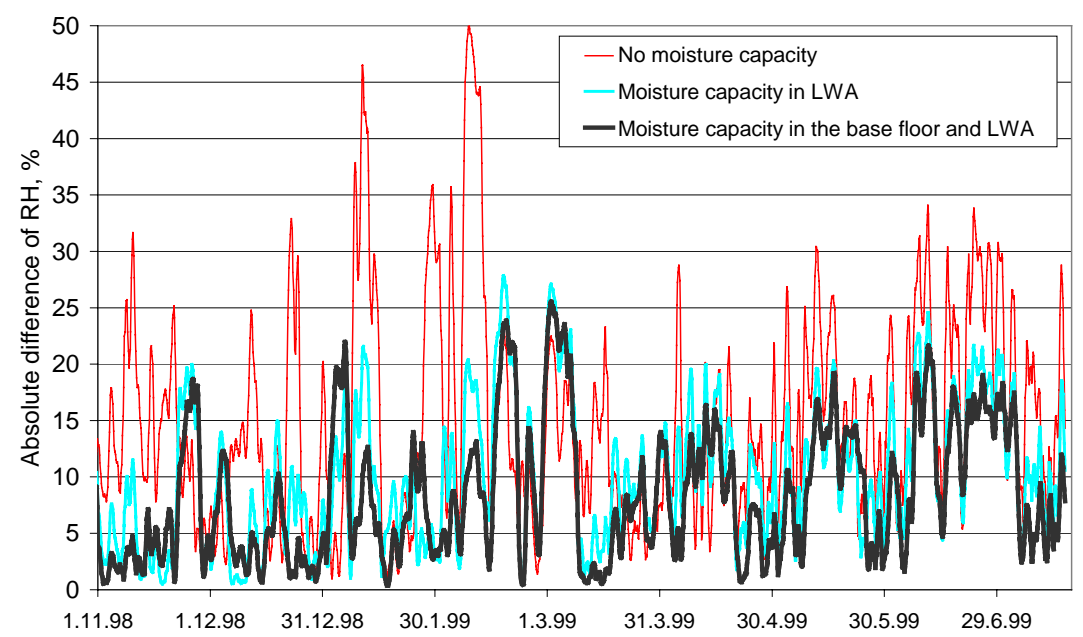

Fig. 7. Absolute difference of RH between measured and calculated values in the cold crawl space.
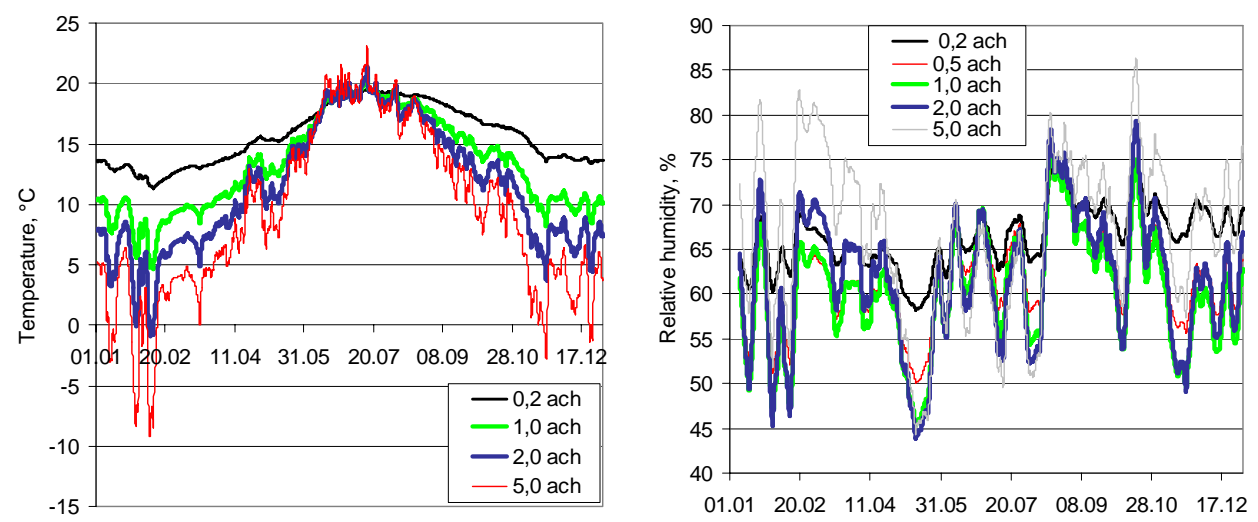

Fig. 9. Calculated 24-hour moving average air temperature (left) and weekly moving averages of $\mathrm{RH}$ (right) in the crawl space at various air change rates; the ground is covered with $17 \mathrm{~cm} \mathrm{LWA.}$ 


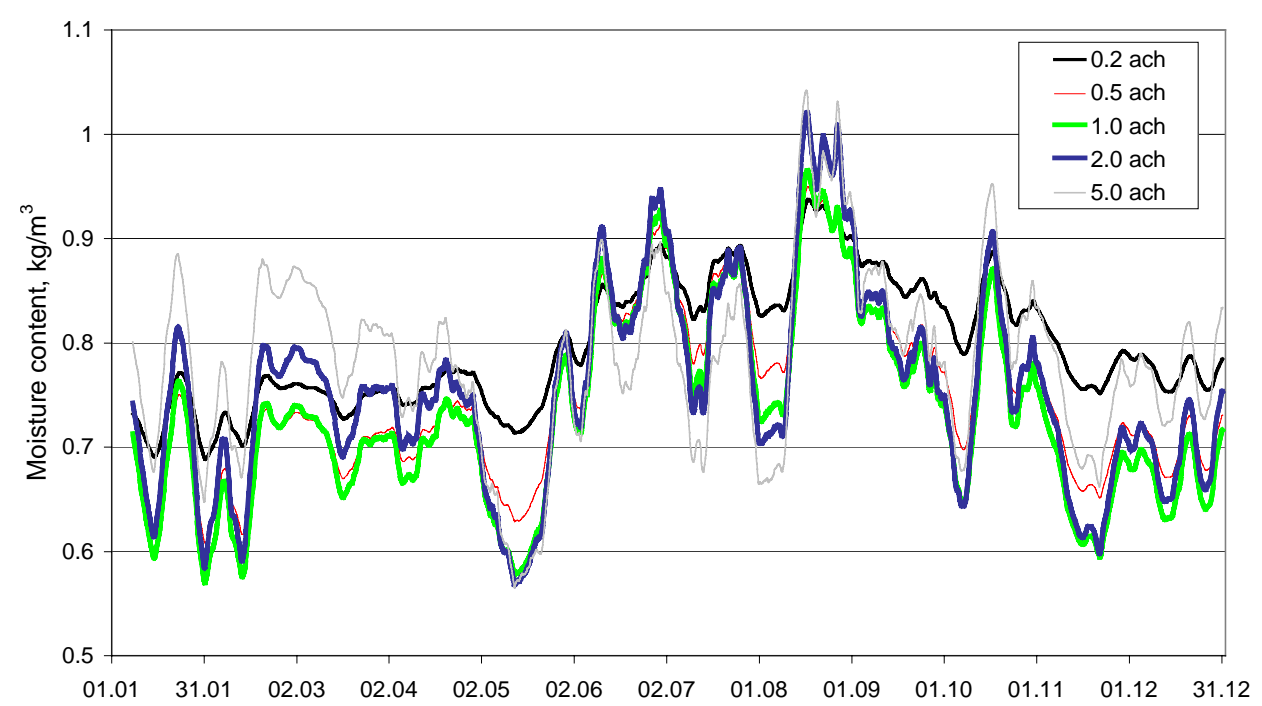

Fig. 10. Moisture content weekly moving average inside the LWA at the depth of $6.7 \mathrm{~cm}$ for different air change rates.
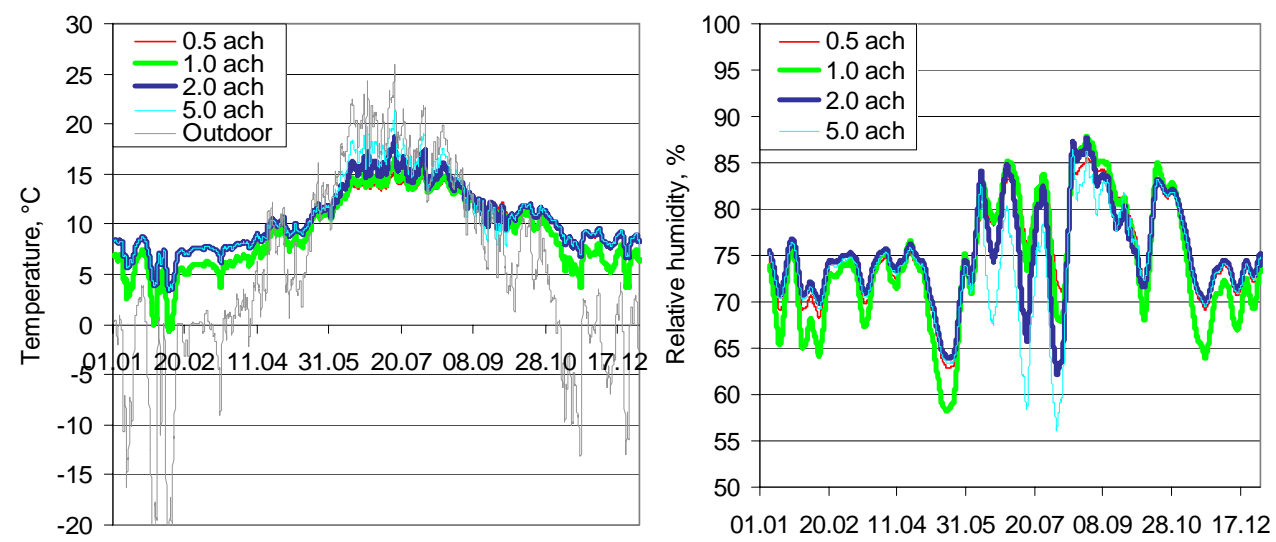

Fig. 11. Crawl space air temperature 24-hour moving average (left) and relative humidity weekly moving average (right) for various air change rates; the ground is covered with a $15 \mathrm{~cm}$ layer of LWA. 


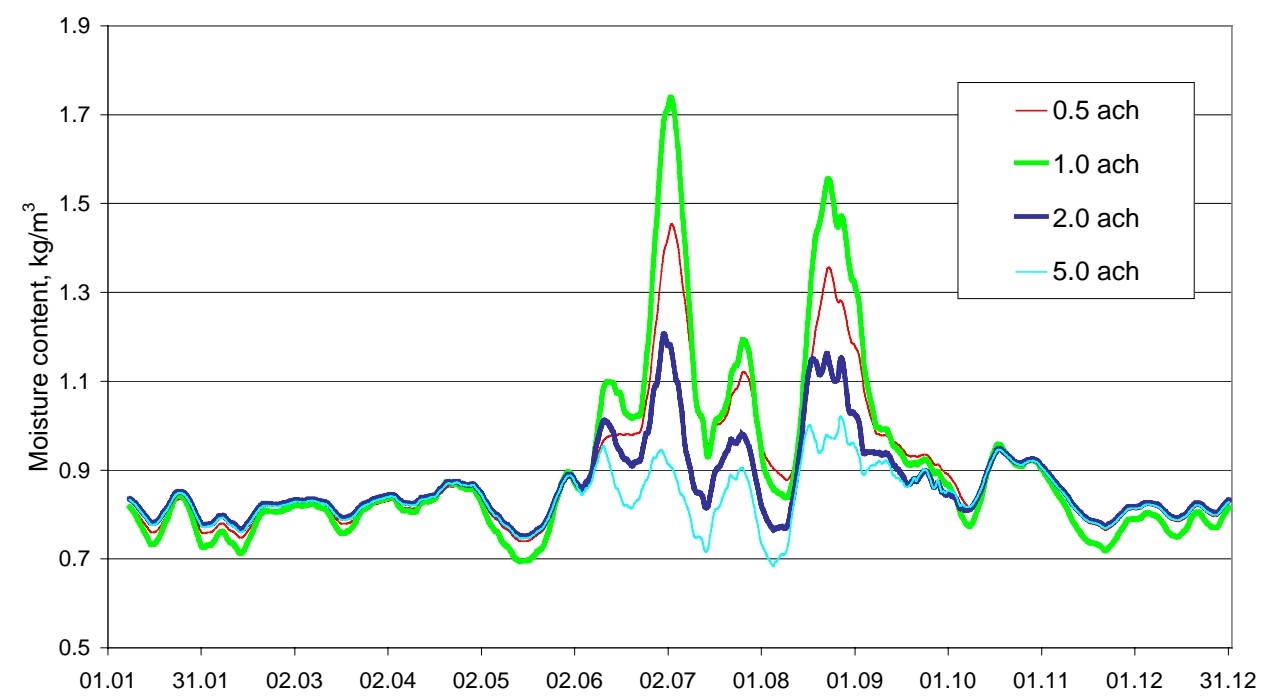

Fig. 12. Moisture content (weekly moving average) inside the LWA at a $5 \mathrm{~cm}$ depth.

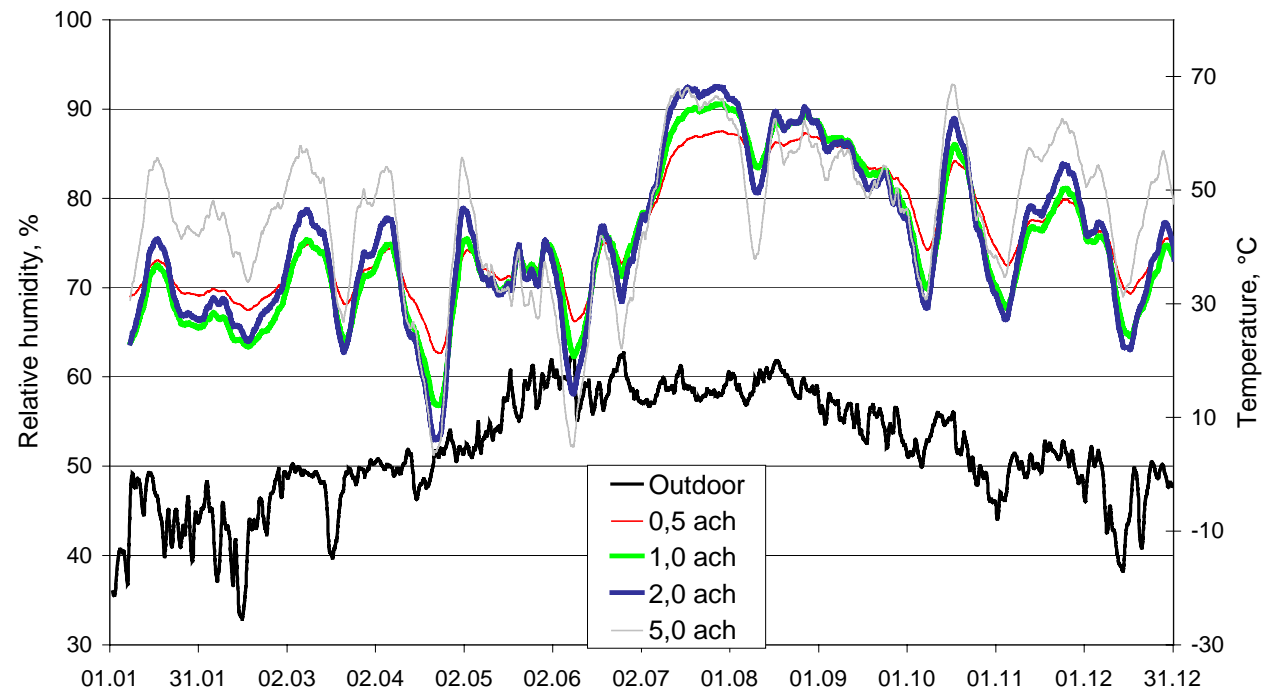

Fig. 13. Relative humidity and outdoor temperature in the cold crawl space when the weather data of the Finnish test-year for energy calculations (1979) is used. 

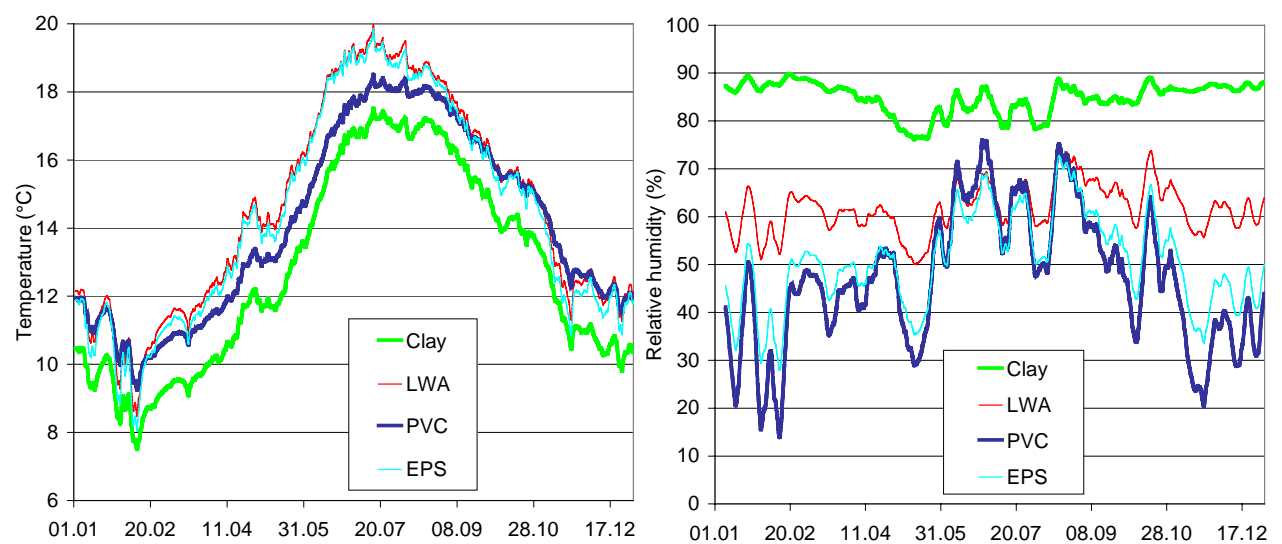

Fig. 14. Crawl space air temperature 24-hour moving average (left) and relative humidity weekly moving average (right) with different ground covers; the air change rate is $0.5 \mathrm{ach}$.

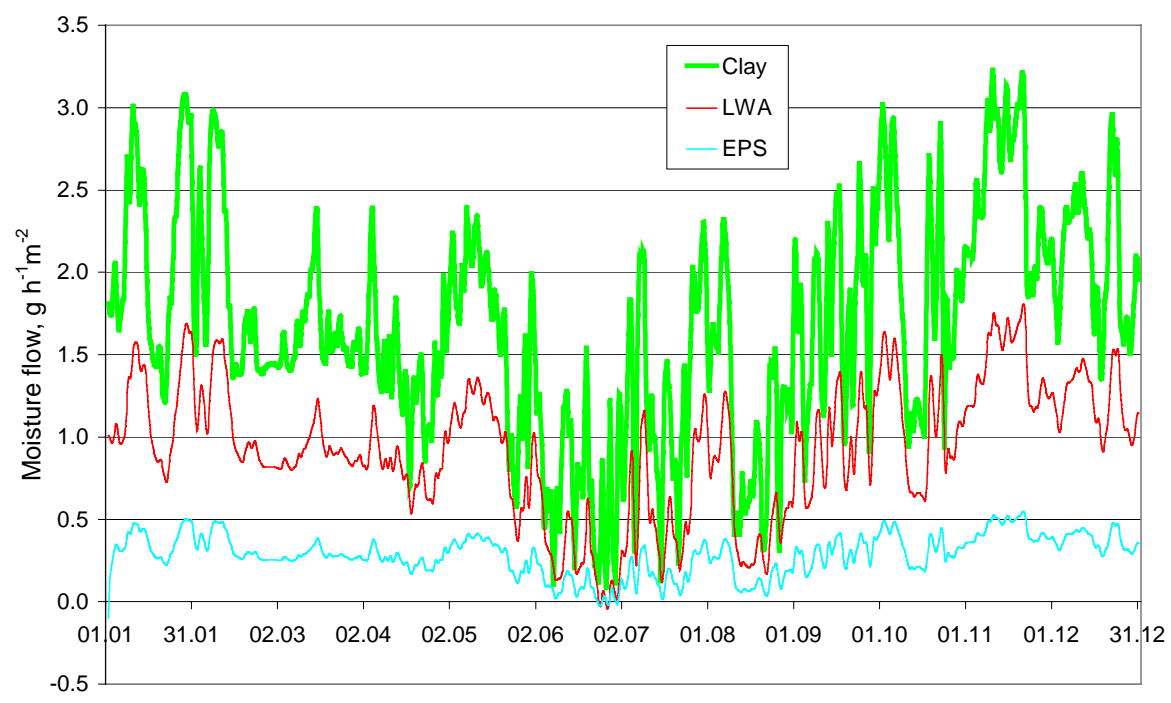

Fig. 15. Moisture flow (24-hour moving average) from the ground; positive values indicate evaporation and negative values moisture flow from air to ground. 

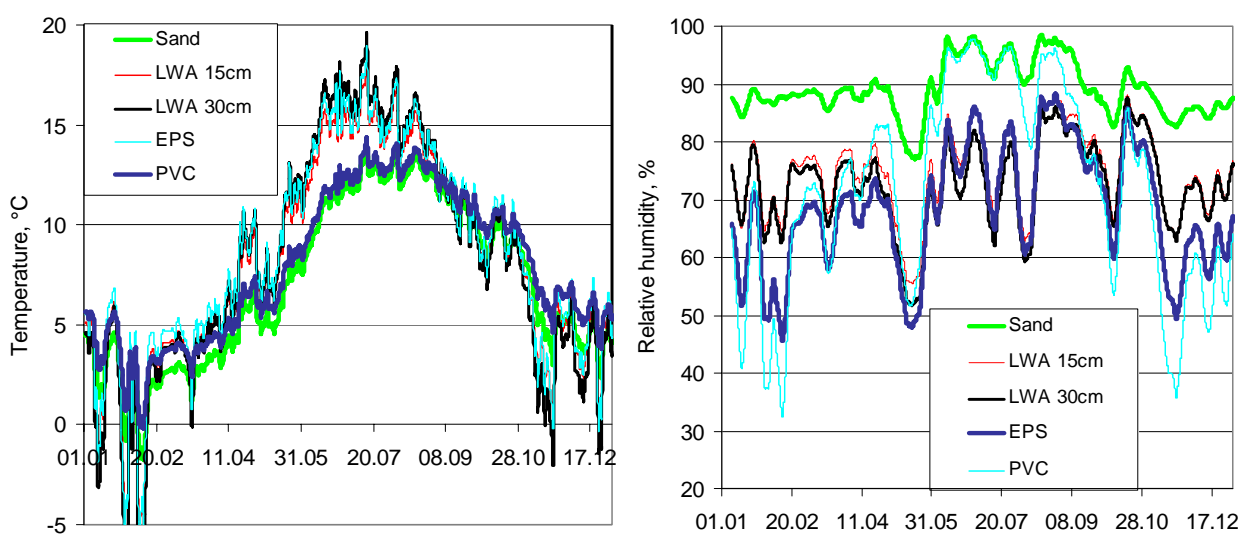

Fig. 16. Crawl space air temperatures (left) and relative humidity (right) for different ground covers air change is 2.0 ach, 24-hour moving averages).

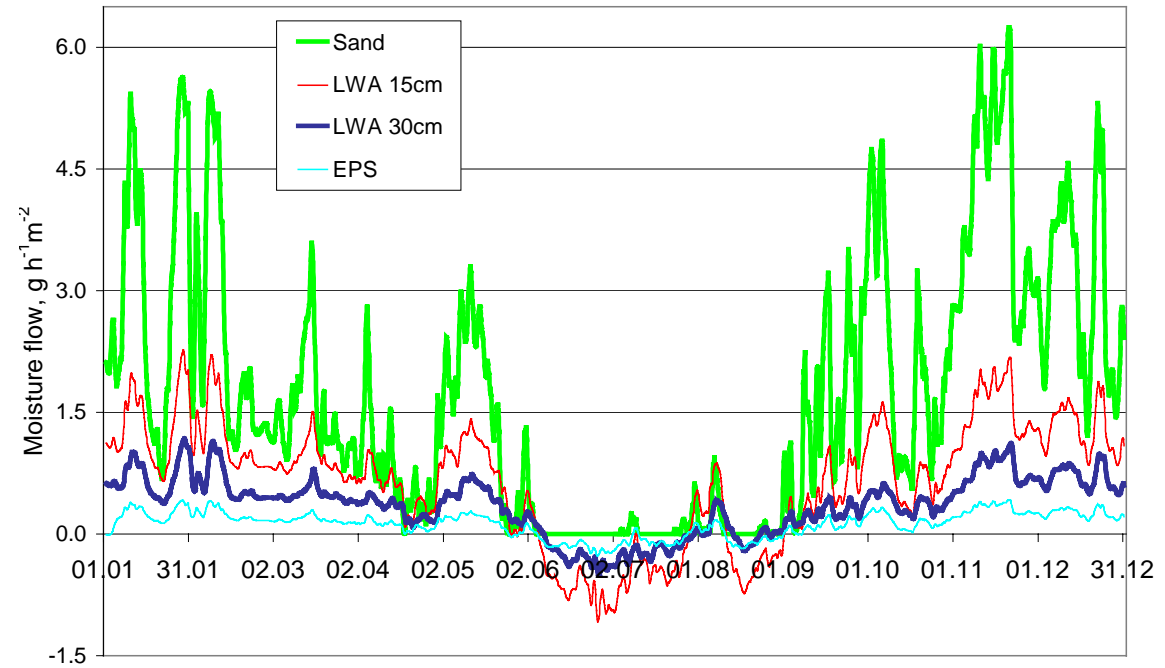

Fig. 17. Moisture flow from the ground (evaporation rate in the case of sand); positive values indicate evaporation and negative values moisture flow from the air to the ground (24-hour moving average). 
role in the inaccuracy of the temperature calculation. This affects the accuracy of the relative humidity as well. However, the calculated relative humidity shows almost perfect agreement with the measured data in the warm crawl space. In the cold crawl space, some disagreements can be seen but these might be caused by complex geometry of the crawl space - the crawl space of the L-shape building had $2 \times 3$ sections, and it was suspected that the air mixing was not complete, causing non-homogeneous temperature and humidity fields.

Thermal and moisture capacity as well as moisture and thermal resistance proved to be important properties of ground covers. A PVC cover (high moisture resistance and a negligible thermal resistance) showed good behaviour in a relatively warm and dry crawl space. In a colder crawl space, a PVC cover did not provide any benefit in the critical summertime because it does not insulate the cold ground from the crawl space. A LWA cover reduced moisture fluctuations due to its moisture capacity. Although a $15 \mathrm{~cm}$ LWA and $5 \mathrm{~cm}$ EPS cover have the same thermal resistance, the EPS insulation cover showed slightly lower RH values in the colder wooden crawl space. That is due to the smaller heat capacity of the EPS cover. The results demonstrate that an ideal ground cover should have a high moisture and heat resistance, a high moisture capacity, and a low heat capacity.

The weather used in the calculations had a significant role on the results. The calculations were mostly carried out with the weather data of 1998 which was considered to be typical. An exceptionally cold and humid summer will make the crawl space moist. If the outdoor air RH already causes mould growth, high RH cannot be avoided in a crawl space ventilated with outdoor air. This was the case when the Finnish test-year for energy calculations, based on the weather data of 1979, was used. Hyppel $\left[{ }^{17}\right]$ and Aberg $\left[{ }^{18}\right]$ have reported similar results, i.e., mould growth in all crawl spaces in 1988. Therefore there are some exceptional years when the mould growth occurs on any wood in contact with outdoor or crawl space air. Thus it is likely that the weather conditions in Finland and in other countries with similar climate force us to accept some mould growth during exceptional years.

The prediction of mould growth is a complicated question. Mould growth depends strongly on the material, temperature, humidity, time, and even on the air movement on the surface. Explicit threshold values for RH in the crawl spaces can not be used since RH higher than $75 \%$ is typical outdoors. Equation (1), used for the prediction of the mould growth, is the best mathematical model available for the mould growth.

\section{CONCLUSIONS}

Relative humidity of the crawl space can be calculated accurately by means of computer simulation when the moisture transfer in the ground cover and base floor is taken into account. A slight disagreement in the results is caused by 
uncertainties in used air change rate values and by the simplified heat transfer in the ground soil.

The simulations showed the effect of moisture capacity in reducing relative humidity fluctuations and even the level of RH and the risk of mould growth in the crawl space during the summer. Important properties of ground covers are their low thermal and high moisture capacity as well as high moisture and thermal resistance. A PVC cover can reduce relative humidity in a warm crawl space but in a cold crawl space, due to its negligible thermal resistance, it does not provide any benefit in the summer when outdoor air is the main moisture source. The $15 \mathrm{~cm}$ LWA and $5 \mathrm{~cm}$ EPS covers have the same thermal resistance, but EPS reduces RH slightly more than the LWA cover. This can be explained by the lower thermal capacity of EPS. Ground covers with a moisture capacity showed significant moisture uptake in the summer (nearly $0.8 \mathrm{~kg} \mathrm{~m}^{-3}, 15 \mathrm{~cm}$ LWA and $0.4 \mathrm{~kg} \mathrm{~m}^{-3}, 5 \mathrm{~cm}$ EPS) which decreased RH in the crawl space. A LWA cover can store much more moisture than an EPS insulation but that did not compensate the effect of the higher heat capacity. When a $30 \mathrm{~cm}$ LWA cover was used, RH was slightly lower than with $5 \mathrm{~cm}$ EPS.

Relative humidity in the crawl space was at its highest with uncovered ground, mostly $80-100 \%$. In the summer, the cold crawl space with PVC cover in the wooden building was as moist as with uncovered ground, temperature being as low as $10-15^{\circ} \mathrm{C}$. The warmer crawl space of the apartment building was very dry; $\mathrm{RH}$ was under $70 \%$ and temperature $16-20^{\circ} \mathrm{C}$ with all ground covers. In the cold crawl space at a 2.0 ach air change rate, the lowest RH in the summer $\left(77 \%\right.$, and $13{ }^{\circ} \mathrm{C}$ on the average), was achieved with a $30 \mathrm{~cm}$ LWA cover. With a $5 \mathrm{~cm}$ EPS cover the average values were almost the same $\left(78 \%, 13^{\circ} \mathrm{C}\right)$ and with a $15 \mathrm{~cm}$ LWA cover somewhat higher $\left(80 \%, 12.5^{\circ} \mathrm{C}\right)$.

Moisture conditions were clearly acceptable in the warmer crawl space because RH remained below 70\%. In the colder crawl space of the wooden building, it was necessary to use the mould growth index to evaluate the acceptability of the conditions in respect of mould growth. The conditions were acceptable with $30 \mathrm{~cm}$ LWA or $5 \mathrm{~cm}$ EPS covers, and air change at least 1.0 ach was assumed. The higher air change rate $(2.0-5.0 \mathrm{ach})$ in the summer provided drier conditions than an air change rate of 0.5 and 1.0 ach did. With $15 \mathrm{~cm}$ LWA, air change 2.0 ach was necessary to use. The uncovered ground and PVC cover produced clearly unacceptable conditions.

The weather data used in the calculations played a significant role. This study was focused on a cold climate, typical of Finland. Using the Finnish test-year for energy calculations, based on the weather data of 1979, the RH of outdoor air already caused mould growth on wood and, therefore, high RH could not be avoided in crawl spaces ventilated with outdoor air. It seems that weather conditions of exceptional years will produce favourable conditions for some mould growth. When RH in the crawl space is higher than $75 \%$, it is rather complicated to assess the acceptability of moisture conditions; in addition, the mould growth index and the prevalence of the weather data should be taken into account. 
In cold crawl spaces, appropriate ground covers and air change rates have to be used to achieve acceptable moisture conditions; $15-30 \mathrm{~cm}$ LWA and 5-10 cm EPS covers can be recommended for any crawl space. A PVC cover should not be used in cold crawl spaces and uncovered ground should never be used in any crawl space. A cold crawl space needs a two-speed air change: $0.5-1.0$ ach in the heating season and 2.0-5.0 ach in the warm season from June to October. In relatively warm crawl spaces, any ground cover and air change rate between 0.5 2.0 ach give acceptable conditions.

\section{ACKNOWLEDGEMENT}

The financial support from The Finnish National Technology Agency TEKES is gratefully acknowledged.

\section{REFERENCES}

1. Kokko, E., Ojanen, T., Salonvaara, M., Hukka, A., and Viitanen, H. Puurakenteiden kosteustekninen toiminta. Technical Research Centre of Finland, VTT Research Notes, No. 1991, Espoo, 1999.

2. Pasanen, A.-L., Juutinen, T., Jantunen, M. J., and Kalliokoski, P. Occurrence and moisture requirements of microbial growth in building materials. Int. J. Biodeterior. Biodegrad., 1992, 30, 273-283.

3. Viitanen, H. and Ritschkoff, A.-C. Mould Growth in Pine and Spruce Sapwood in Relation to Air Humidity and Temperature. Swedish University of Agricultural Sciences, Department of Forest Products, Report No. 221, Uppsala, 1991.

4. Hallenberg, N. and Gilert, E. Mikrobiologiska analyser av prover från byggnad. Borås Statens Provningsanstalt, Rapport 19, Gothenburg 1993.

5. Nevander, L. E. and Elmarsson, B. Fuktdimersionering av träkonstruktioner, Riskanalys. Swedish Council of Building Research, Report R38, Stockholm, 1991.

6. Viitanen, H. Modeling the time factor in he development of mould fungi - Effect of critical humidity and temperature conditions in pine and spruce sapwood. Holzforschung, 1996, 51, 6-14.

7. Viitanen, H., Hanhijärvi, A., Hukka, A., and Koskela, K. Modelling mould growth and decay damages. In Proc. Conference Healthy Buildings 2000. Espoo, Finland, 3, 341-346.

8. Viitanen, H. Factors Affecting the Development of Mould and Brown Rot Decay in Wooden Material and Wooden Structures. Effect of Humidity, Temperature and Exposure Time. Dissertation, Swedish University of Agricultural Sciences, Uppsala, 1996.

9. Sahlin, P. Modelling and Simulation Methods for Modular Continuous Systems in Buildings. Dissertation, Royal Institute of Technology, Stockholm, 1996.

10. Sahlin, P. and Sowell, E. F. The Neutral Model Format for Building Simulation. Bris Data Ab and Royal Institute of Technology, Stockholm, 1996.

11. Sahlin, P. NMF Handbook. An Introduction to the Neutral Model Format, NMF version 3.02. Royal Institute of Technology, Stockholm, 1996.

12. Kurnitski, J. and Matilainen, M. Moisture conditions in outdoor air-ventilated crawl spaces of apartment buildings in a cold climate. Energy and Build., 3, 15-29.

13. Kurnitski, J. and Vuolle, M. Simultaneous calculation of heat, moisture, and air transport in a modular simulation environment. Proc. Estonian Acad. Sci. Eng., 2000, 6, 25-47.

14. Lampinen, M. J. Aineensiirto-oppi. Helsinki University of Technology, Laboratory of Applied Thermodynamics, Report 94, Otaniemi, 1996. 
15. Kurnitski, J. Ground moisture evaporation in crawl spaces, Build. Environ. (in print).

16. Tammelin, B. and Erkiö, E. Weather Data for Energy Calculations - The Finnish Test-year. Finnish Meteorological Institute, Weather Department, Technical Climatology, Report 7, Helsinki, 1987.

17. Hyppel, A. Project miljövänlig barnstuga i Skarparby. Kungliga Tekniska Högskolan, Stockholm, 1990.

18. Åberg, O. CICS, Calculation in Crawl Spaces. In Proc. 3rd Symposium of Building Physics in the Nordic Countries. Copenhagen, 1993, 579-586.

\title{
Alt tuulutatava põranda niiskusrežiimi kujundamine ehitistes
}

\author{
Miimu Airaksinen, Jarek Kurnitski ja Olli Seppänen
}

Pinnase kattekihi ja põranda niiskusmahtuvuse puhverefektide ning teiste omaduste mõju alt tuulutatava põranda niiskusrežiimile on määratud dünaamilise simulatsiooniga. Otsiti võimalusi tuulutatud põrandaaluse suhtelise niiskuse vähendamiseks pinnase kattekihi ja ventilatsiooni optimaalse valiku teel, hinnates seejuures põrandaaluse keskkonna aktsepteeritavust hallituse kasvu indeksiga. Tulemused näitavad niiskusrežiimi suurt sõltuvust põrandaaluse temperatuurist. Suhteliselt soojema keskkonna puhul ei esinenud niiskusprobleeme - kõik pinnase kattekihid, v.a katmata pinnas, ja ventilatsioon vahemikus 0,5-2 õhuvahetust tunnis tagasid vastuvõetavad tingimused. Külmema põrandaaluse korral muutus niiskusolukord kriitiliseks ja selle aktsepteeritavuse hindamisel lähtuti hallitusindeksist. Vastuvõetavate tingimuste saavutamiseks oli vaja kasutada 15$30 \mathrm{~cm}$ paksust keramsiidi või $5-10 \mathrm{~cm}$ paksust vahtpolüstürooli kihti. Ventilatsioon 0,5-1 õhuvahetust tunnis tagas madalaima suhtelise niiskuse kütteperioodil, kuid suvel oli vajalik põrandaaluse soojendamiseks lisada ventilatsiooni 2-5 õhuvahetuseni tunnis. Soojusisolatsioon ja niiskusmahtuvus osutusid kriitilistes tingimustes pinnase kattekihi olulisteks omadusteks, mis aitasid saavutada vastuvõetavaid tingimusi. 